\title{
Türkiye'deki Uluslararası İlişkiler Akademisyenleri ve Bölümlerinin Akademik Etkilerinin Google Scholar Verilerinden Hareketle İncelenmesi
}

A Study for Scholarly Impacts of International Relations Academics and Departments in Turkey through Google Scholar Data

Ali BALCI
Doç. Dr., Ortadoğu Enstitüsü ve Uluslararası İlişkiler Bölümü, Sakarya Üniversitesi

\section{Filiz CİCíŏ̆LU}

Dr. Öğr. Üyesi, Uluslararası İlişkiler Bölümü, Sakarya Üniversitesi

\section{Duygu KALKAN}

Doktora Adayı, Uluslararası İlişkiler Bölümü, Sakarya Üniversitesi

\section{Bu makaleye atıf için}

Balc1, Ali; Cicioğlu, Filiz ve Kalkan, Duygu, “Türkiye'deki Uluslararası İlişkiler Akademisyenleri ve Bölümlerinin Akademik Etkilerinin Google Scholar Verilerinden Hareketle İncelenmesi", Uluslararası İlişkiler, Cilt 16, Say1 64, 2019, s. 57-75, DOI: $\underline{10.33458 / \text { uidergisi.652913 }}$

Makaleye Erişim İçin: https://dx.doi.org/10.33458/uidergisi.652913

Makale Gönderim: 07 Aralık 2018

Son Düzeltme: 23 Eylül 2019

İnternet Yayım: 01 Aralık 2019

Basım Tarihi: 01 Aralık 2019

Uluslararası İlişkiler Konseyi Derneği | Uluslararası İlişkiler

E-Posta: bilgi@uidergisi.com.tr

Bu makalenin tüm hakları Uluslararası Illişkiler Konseyi Derneğìne aittir. Önceden yazılı izin almadan hiçbir iletişim, kopyalama ya da yayın sistemi kullanılarak yeniden yayımlanamaz, çoğaltılamaz, dağıtılamaz, satılamaz veya herhangi bir ssekilde kamunun ücretli/ücretsiz kullanımına sunulamaz. Akademik amaçlı alıntılar bu kuralın dışındadır. Yazıda belirtilen fikirler yalnızca yazarına/yazarlarına aittir. UİK Derneğini, editörleri ve diğer yazarları bağlamaz. 


\title{
Türkiye'deki Uluslararası İlişkiler Akademisyenleri ve Bölümlerinin Akademik Etkilerinin Google Scholar Verilerinden Hareketle İncelenmesi
}

\author{
Ali BALCI \\ Doç. Dr., Sakarya Üniversitesi, Ortadoğu Enstitüsü ve Uluslararası İlişkiler Bölümü, Sakarya. \\ E-posta:alibalci@gmail.com \\ Filiz CİCİOĞLU \\ Dr. Öğr. Üyesi, Sakarya Üniversitesi, Siyasal Bilgiler Fakültesi, Uluslararası İlişkiler Bölümü, Sakarya. \\ E-posta:fsever@sakarya.edu.tr \\ Duygu KALKAN \\ Doktora Adayı, Sakarya Üniversitesi, Siyasal Bilgiler Fakültesi, Uluslararası İlişkiler Bölümü, Sakarya. \\ E-posta: ozduygu@windowslive.com
}

\section{ÖZET}

Günümüzde bilgisayarlar geniş verileri toplama ve değerlendirme imkanını ortaya çıkarınca, akademisyenlerin etkisini ölçmeyi hedefleyen çalışmalarda ciddi bir artış olmuştur. Elinizdeki çalışma da Google Scholar (GS) atıf sayısı verileri üzerinden Türkiye’deki Uluslararası İlişkiler akademisyenlerini ve bölümlerini analiz etmeyi hedeflemektedir. Yapılacak bu analiz ile, mevcut ölçme listelerine alternatif olarak akademisyen ve bölümlerin yeni bir sıralanması ortaya konulmaktadır. GS verilerinden hareketle elde edilen sonuçlar, kontrol amacıyla Social Sciences Citation Index (SSCI) veri tabanından derlenen makale sayıları ve atıflar ile karşılaştırılmışıtır. Böylelikle çalışma Türkiye özelinde gittikçe kapsamlı bir hale gelen nitelik değerlendirme literatürüne, verilere dayalı bir katkı yapmayı hedeflemektedir.

Anahtar Kelimeler: Uluslararası İlişkiler Bölümleri, Google Scholar Atıfları, Uluslararası İlişkiler Akademisyenleri, Siralama.

\section{A Study for Scholarly Impacts of International Relations Academics and Departments in Turkey through Google Scholar Data}

\begin{abstract}
Since computers revealed the possibility to collect and evaluate large data, there has been a significant increase in studies measuring the impact of academics. This study aims to analyse International Relations scholars and departments in Turkey by using the data from Google Scholar citation counts. Through this measurement, the study will generate a new ranking list as alternative to existing measurement lists. To control outcomes, Google-generated ranking lists will be compared with data generated from Social Sciences Citation Index (SSCI). Thus, the study aims to make a data-based contribution to the quality assessment literature, which has become increasingly popular in Turkey.

Keywords: International Relations Departments, Google Scholar Citations, International Relations Scholars, Ranking
\end{abstract}




\section{Giriş}

Bu çalışmada amaç, Türkiye'deki 'Uluslararası İlişkiler' (Ui) ile 'Siyaset Bilimi ve Uluslararası İlişkiler' (SBUI) bölümlerinin ve Uİ alanında çalışan öğretim üyelerinin akademik etkilerini (scholarly impact) Google Scholar (GS) aracıllğıyla toplanan atıf sayıları (citation counts) üzerinden bir sıralamaya (ranking) tabi tutmaktır. ${ }^{1}$ İlgili bölümlerde Kasım 2018 tarihi itibariyle aktif olarak çalışan öğretim üyelerinin aldığı atıf sayıları üzerine temellenen böylesi bir çalışmanın literatür ve pratik düzeyde üç önemli katkı yapması beklenmektedir. Birincisi, çalışmanın ortaya çıkardığı sonuçlar ile farklı verilerden hareketle yapılan mevcut sıralamaları test etmek ve karşılaştırmak mümkündür. Çalışmanın ikinci katkısı, son yıllarda özellikle Amerikan üniversiteleri için popüler hale gelen GS verileri üzerinden yapılan sıralama çalışmalarını Türkiye'den bir bölüm örnek olayı üzerinden Türkçe literatüre kazandırmaktır. Son ve pratik düzlemde beklenen katkı ise Türkiye'deki Uİ eğitiminin gelişmesi ile ilgilidir. Özellikle araştırma odaklı lisans üstü eğitimin hangi üniversitelere odaklanması noktasında, akademisyenlerin yayın performansı ve kalitesini ölçen GS verileri bilimsel yönü güçlü bölümlerin tespit edilmesinde girdilerden biri olabilir. ${ }^{2}$

Öğretim üyeleri ile bağlı bulundukları kurumların ${ }^{3}$ akademik etkilerinin (scholarly impact) ölçülmesinde toplam yayın sayıları, prestijli platformlarda yayın yapma oranı ve yayınlara alınan toplam atıflar gibi veriler kullanılmaktadır. ${ }^{4} \mathrm{Bu}$ çalışmalar ile, toplam yayın sayısı ya da yayınlara verilen atıfların sayısı üzerinden bir sıralama yapıldığında hangisinin bizi daha sağlıklı bir sonuca ulaştıracağ1 sorusu önemli ölçüde çözülmüş durumdadır. Asgari bilimsel kriterleri karşılamayan platformlarda (predatory publications) çok sayıda yayın yapma ${ }^{5}$ imkanından hareketle, ikincisinin daha fazla akademik etkinlik göstergesi olduğu düşünülmektedir. ${ }^{6}$ Bir başka tartışma da, alınan atıf sayılarının değil, etki faktörü yüksek dergilerde yapılan yayınların toplamının bir etkinlik göstergesi olduğuna ilişkindir. ${ }^{7}$ Her iki yöntem de önemli açıklar barındırmaktadır. Toplam atıf sayıları, kendi kendine atıf (self-citation) ve bir akademik camianın karşılıklı atıfları ile objektif bir kriter olmaktan

1 Bu yöntemle $A B D$ 'deki Siyaset Bilimi bölümleri ve akademisyenlerine yönelik yapılmış bir çalışma için bkz. Michael Peress, "Measuring the Research Productivity of Political Science Departments Using Google Scholar", PS: Political Science \& Politics, Cilt 52, No 2, 2019, ss. 312-317

2 Lisansüstü eğitimde öğretim üyelerinin bilgi sahibi olmak ve akademik çalışma yapmada yetkin olmanın dişında bu bilgi ve deneyimleri öğrencilere aktarma noktasında da yetkinliği (iyi bir eğitmen olması) önemli kriterdir. Bkz. Jacqui Briggs, "Political Science Teaching Across Europe", Political Science \& Politics, Cilt 49, No 4, 2016, ss. 828-833.

3 Çalışma ilgili akademisyenlerin verilerin toplanıldığı tarihte bağlı bulundukları kurumları temel almaktadır. Verilerin toplandığı tarihten sonra kurum değiştirenler olabileceği gibi, bu tarihten çok kısa süre önce ilgili kuruma katılanlar da olabilir. İkinci grupta olan akademisyenler çalışmalarının önemli bir kısmını daha önce bulundukları kurumlarda yapmış olabilirler. Web of Science kurumlar üzerinden yayın ve atıf performansı ölçümüne imkan sağlasa da, Google Scholar üzerinden bu problemi çözmek kolay değildir. Elle yapılacak tasnifler de eksik veriler (kimin hangi tarihte hangi kurumda istihdam edildiği gibi) nedeniyle yanıltıcı olabilir.

4 Bkz. James C. Garand, and Kristy L. Graddy, “Ranking Political Science Departments: Do Publications Matter?”, PS: Political Science \& Politics Cilt 32, No 1, 1999, ss. 113-116.

5 Bkz.J. Beall, “Predatory Open-access Scholarly Publishers”, The Charleston Advisor, Cilt 11, No 4, 2010, ss. $10-17$.

6 Bu konuda bkz. Arthur H. Miller et al. "Department Rankings: An Alternative Approach.” PS: Political Science and Politics, Cilt 29, No 4, 1996, ss. 704-728.

7 Örneğin Türkiye adresli yayınlar SSCI dergilerde yayımlanmış olsa bile, çok büyük bir ağırlıkta Türkiye adresli başka yayınlardan atıf almakta, teori dergi ve makalelerine birer girdiye dönüşmemektedir. Bkz. Emre İşeri ve Nevra Esentürk, “Türkiye'de Uluslararası İlişkiler Çalışmaları: Merkez-Çevre Yaklaşımı”, Elektronik Mesleki Gelişim ve Araştırmalar Dergisi, Cilt 2, 2016, ss. 17-33. 
çıarken ${ }^{8}$, nitelikli platform yayınlarını ölçen mevcut sistemlerin kitapları ve İngilizce dışındaki dillerde yapılan yayınları yeterince kapsamama sorunu vardır.

Atıf sayılarının akademik etkinliği/katkıyı ölçüp ölçmediğine ilişkin mevcut tartışmaya rağmen, atıf sayıları hızlı bir şekilde kurumsal kararları belirleyen önemli bir girdiye dönüşmüştür. Örneğin, atama ve yükseltme kararları ile, maaşlar, araştırma ödenekleri ve ödüller gibi konularda kurumsal kararlar verilirken atıf sayıları dikkate alınan önemli verilerden birisi haline gelmiştir. ${ }^{9}$ Elbette atıf sayısı akademisyenlerin ve bölümlerin akademik etkinliğini ortaya koymada tek kriter değildir. Örneğin, yeni bir fikir ortaya atmak ve bunu geliştirmek, etkili ve kullanışlı bir ders kitabı yazmak, disiplinin örgütlenmesinde ve kurumsallaşmasında profesyonel bir rol oynamak gibi çok sayıda etkinlik (impact) kriteri sayılabilir. ${ }^{10}$ Fakat bunlara ilişkin veri ortaya koymak ya da atıf sayılarından çıkan sıralamayı bu verileri kontrol değişkeni olarak kullanmak yoluyla test etmek altından kalkılması epey zorlu (ve sıklıkla sübjektif) bir girişimdir. Dolayısıyla elinizdeki çalışma, Masuoka, Grofman ve Feld'in benzer çalışmalarından yola çıkarak, atıf sayısı verilerini (citation count data) akademik etkinliğin ölçülmesinde temel girdi olarak almaktadır. ${ }^{11}$

Mevcut en kapsamlı veriyi sağlayan GS üzerinden elde edilen atıf sayılarından hareketle bir sıralama yapmayı hedefleyen bu çalışma, bir bölümün ya da öğretim üyesinin neden daha fazla atıf aldığı sorusu ile ilgilenmemektedir. ${ }^{12}$ Bölümlerin ve öğretim üyelerinin akademik etkisinin Google Scholar atıfları üzerinden bir tasvirini sunmayı hedefleyen çalışma, şu şekilde ilerleyecektir. İlk olarak Türkiye'deki mevcut ölçme alternatifleri ve eksikleri tartışlacaktır. İkinci olarak, çalışma için ihtiyaç duyulan verilerin GS'den nasıl toplandığı anlatılacaktır. Yine bununla ilgili olarak, toplanan verilerden en sağlıklı sonucu elde edebilmenin önündeki engellerden ve çözümlerinden bahsedilecektir. $\mathrm{Bu}$ kısımda Web of Science (WoS) içinde sosyal bilim dergilerini tarayan Social Science Citation Index (SSCI) kapsamındaki makale sayıları ve atıflarının ${ }^{13}$ kontrol değişkeni olarak sıralama işlemine dahil edilme gerekçesi de açıklanacaktır. Üçüncü olarak, GS ve SSCI verilerinden hareketle hangi sıralamaların yapılacağı anlatılacaktır. En sonda ise, hem GS hem de SSCI analiz sonuçları paylaşılarak, bunların kısa bir değerlendirmesi sunulacaktır.

8 Türkiye’deki kötü bir örnek için bkz. Umut Al ve İrem Soydal, "Dergi Kendine Atıfının Etkisi: Energy Education Science and Technology Örneği”, Türk Kütüphaneciliği, Cilt 26, No 4, 2012, ss. 699-714. Bu çalışmada incelenen derginin "Web of Science” sisteminde 6 yıl kaldığı göz önüne alınırsa toplam atıflardan kaynaklanan bu sorunların nitelikli platformlar için de kısmen geçerli olduğu söylenebilir. Bu konuda ayrıca bkz. Güleda Doğan et al., "Web of Science'tan Çıkarılan Türkiye Adresli Dergiler Üzerine Bir Araştırma”, Türk Kütüphaneciliği, Cilt 32, No 3, 2018, s. 151-162; Türkiye’de Üniversitelerarası Kurul (ÜAK), bu makalenin değerlendirme sürecinde olduğu bir zamanda, 9 Mart 2019 tarihinde yağmacı dergiler ile ilgili bir karar aldı ve bu dergilerde yayımlanan çalışmaların “akademik yükseltmelerde dikkate alınmamasını kararlaştırdı”. Bkz. “'Yağmacı' Dergi Yayınları Akademik Yükseltmelerde Kullanılamayacak”, 9 Mart 2019,https://www.yok.gov.tr/Sayfalar/ Haberler/yagmaci-dergi-yayinlarina-onlem.aspx (Erişim Tarihi 20 Temmuz 2019)

9 Daniel B. Klein ve Eric Chiang, “The Social Science Citation Index: A Black Box--With an Ideological Bias?”, Econ Journal Watch, Cilt 1, No 1, 2004, ss. 134-165

10 Örneğin bkz. Albert Somit ve Joseph Tanenhaus, The Development of American Political Science: From Burgess to Behavioralism, New York, Boston, Allyn and Bacon, 1967, ss. 67-70

11 Natalie Masuoka et al., “The political science 400: A 20-year update.” PS: Political Science \& Politics, Cilt 40, No 1, 2007, ss. 133-145.

12 Akademik verimliliği etkileyen unsurlar ve bu unsurlar hakkında bir literatür değerlendirmesi için bkz. Vicki L. Hesli ve Jae Mook Lee, “Faculty Research Productivity: Why Do Some Of Our Colleagues Publish More Than Others?”, PS: Political Science \& Politics, Cilt 44, No 2, 2011, ss. 393-408.

13 Bkz. J. Ioannidis et al., "Who is Afraid Of Reviewers' Comments? Or, Why Anything Can Be Published And Anything Can Be Cited”, European Journal of Clinical Investigation, Cilt 40, No 4, 2010, ss. 285-287. 


\section{Mevcut Ölçümler ve Sorunları}

Türkiye'deki uluslararası ilişkiler bölümlerini sınıflandırmada bir çok kriter kullanılmıştır. Bunlardan en eski olanı lisans düzeyinde öğrencilerin üniversiteye girişteki tercih önceliklerinin ortaya çıkardığı giriş puanlarını temel alan sıralamadır. ÖSYM tarafından yapılan merkezi sınavlar sonucunca ilgili bölümlere yerleştirilebilmek için gerekli taban puanlarından hareketle yapılan bu sıralama her yıl yenilenmekte ve ÖSYM’nin üniversite giriş kılavuzlarında yayımlanmaktadır. Fakat öğrenci tercihlerinde akademik yayın performansı tek kriter değildir. Üniversitenin bulunduğu şehir, kampüs imkanları, bölümün bulunduğu üniversitenin kamuoyundaki itibarı, verilen eğitimin dili, öğrenci sayıları, burs imkanları gibi çok sayıda kriter bu tercihleri belirlemektedir. Dolayısıyla, öğrenci tercihleri ile ortaya çıkan sıralama ile bölümlerin yayın performansı üzerinden sıralanması önemli oranda örtüşse de (bkz. Tablo 1), ilki nitelik noktasında net bir sonuç vermekten uzaktır. Bu nedenle, öğrenci tercihlerinin ortaya çıkardı̆̆ı bu ölçme yöntemi dışında, araştırmacılar veriye dayalı farklı ölçme ve sıralama teknikleri geliştirmişlerdir. ${ }^{14}$

$\mathrm{Bu}$ tekniklerden ilki uluslararası ilişkiler mensubu isimler arasında yapılan anketler yoluyla, ilgili bölüm mensuplarının tanınma sıralamasını ortaya koymaktır. ${ }^{15}$ Türkiye özelinde Mustafa Aydın ve meslektaşlarının yaptığı bu çalışma(lar), "Sizin dışınızda, Türkiye'de Uluslararası İlişkiler alanında son yıllarda en etkili/ilgi çekici çalışmaları kimlerin yaptığını düşünüyorsunuz?” sorusuna verilen cevap üzerinden akademisyenlere ilişkin bir sıralama ortaya çıkarmaktadır. ${ }^{16}$ Aynı çalışmada akademisyenleri sıralamak amacıyla sorulan bir başka soru da şu şekildedir: "Sizin dışınızda, Türkiye'de Uluslararası İlişkiler alanının gelişimine ve kurumsallaşmasına en fazla katkıyı kimlerin yaptığını düşünüyorsunuz?” ${ }^{17}$ Aynı araştırmada bölüm sıralamasını ise yine iki soruya verilen cevaplar ile belirlemektedir: “Türkiye' de lisans düzeyinde en iyi Uluslararası İlişkiler eğitimi veren üniversiteleri sıralayınız” ve “Türkiye'de lisansüstü düzeyde en iyi Uluslararası İlişkiler eğitimi veren üniversiteleri sıralayınız" ${ }^{18}$ Fakat Türkiye'deki Uİ bölümlerinde çalışan akademisyenler arasında gerçekleştirilen anketler üzerinden hazırlanan bu sıralamalar, bölümler ve hocalarının yayın performansı hakkında değil, algılanışlarına dair bir veri ortaya koymaktadır.

14 Bkz. Masuoka, Grofman, ve Feld, “The Political Science 400”, s. 133

15 Bu yöntemi kullanarak yapılan ölçümlerin ilk örnekleri için bkz. Somit ve Tanenhaus, The Development Of Political Science; Walter Roettiger, "Strata and Stability: Reputations of American Political Scientists" PS: Political Science and Politics, Cilt 11, No 1, 1978, ss. 6-12.

16 Mustafa Aydın ve Korhan Yazgan, “Türkiye’de Uluslararası İlişkiler Akademisyenleri Araştırma, Eğitim ve Disiplin Değerlendirmeleri Anketi - 2009”, Uluslararası İlişkiler, Cilt 7, No 25, 2010, ss. 3-42.

17 Aydın ve Yazgan, "Türkiye’de Uluslararası İlişkiler Akademisyenleri”, s. 26

18 Aydın ve Yazgan, “Türkiye’de Uluslararası İlişkiler Akademisyenleri”, s. 34. 
Tablo 1: Uluslararası İlişkiler Bölümlerine İlişkin Mevcut Sıralamalar

\begin{tabular}{|c|c|c|c|}
\hline & ÖSYM $(2018)^{19}$ & ULAKBİM $(2014)^{20}$ & Aydın vd. $(2016)^{21}$ \\
\hline 1 & Koç Uİ $(490,356)$ & Bilkent Uİ (82) & ODTÜ Uİ (85.31) \\
\hline 2 & Sabancı UÇ $(473,186)$ & Koç Uİ (37) & Bilkent Uİ (74.01) \\
\hline 3 & Boğaziçi SBUİ $(466,613)$ & ODTÜ Uİ (31) & Boğaziçi SBUI (62.15) \\
\hline 4 & Galatasaray Uİ $(451,106)$ & Sabancı UÇ (25) & Koç Uİ (44.63) \\
\hline 5 & Bilkent Uİ $(448,323)$ & Boğaziçi SBUİ (20) & Ankara Ü. UI (35.59) \\
\hline 6 & Özyeğin Uİ $(435,034)$ & Hacettepe Uİ (15) & Sabancı UÇ (30.51) \\
\hline 7 & ODTÜ UI $(408,871)$ & Kadir Has Uİ (15) & Kadir Has Uİ (21.47) \\
\hline 8 & TOBB SBUİ $(415,068)$ & TOBB SBUI (14) & Marmara Uİ (14.69) \\
\hline 9 & İb Haldun SBUI $(394,317)$ & Bilgi Uİ (13) & İÜ SBF SBUİ (14.69) \\
\hline 10 & Bilgi Uİ $(392,952)$ & Ankara Ü. Uİ (11) & Bilgi Uí (10.73) \\
\hline 11 & Bahçeşehir SBUİ $(390,970)$ & Işık Uİ (10) & \\
\hline 12 & Kadir Has Uİ $(377,476)$ & Dokuz Eylül Uİ (10) & \\
\hline 13 & İzmir Eko SBUİ $(376,679)$ & İzmir Eko SBUİ (9) & \\
\hline 14 & MEF SBUİ $(375,055)$ & Fatih Ü. Uİ (9) & \\
\hline 15 & Yeditepe SBUİ $(373,896)$ & YTÜ SBUİ (7) & \\
\hline 16 & İ. Şehir SBUİ $(370,877)$ & İTÜ (7) & \\
\hline 17 & İÜ SBF SBUİ $(367,494)$ & Marmara Uİ (7) & \\
\hline 18 & İ. 29 Mayıs SBUİ $(367,063)$ & Bahçeşehir SBUİ (7) & \\
\hline 19 & Marmara Uİ $(361,669)$ & Atılım Uİ (5) & \\
\hline 20 & Hacettepe Uİ $(359,728)$ & Okan Uİ (5) & \\
\hline
\end{tabular}

Veriye dayalı ikinci yöntem, nitelikli dergilerde yapılan yayınların toplamı veya bu yayınlara verilen atıfların toplamı üzerinden sıralama yapmaktadır. ${ }^{22}$ Türkiye' deki Uİ bölümleri için bu yöntemi TÜBİTAK ULAKBİM kullansa da, Uİ akademisyenleri için bu yöntem kullanılarak yapılan sistematik bir çalışma mevcut değildir. 2015 yılında ULAKBİM'in hazırladığı listede 2004-2014 yıllarında Türkiye'deki uluslararası ilişkiler bölümlerinde basılan Web of Science (WoS) endeksli çalışmalar ve bu yayınların aldığı atıflar hesaba katılmıştır. Fakat WoS verilerinden hareketle yapılan sıralamaların iki önemli sorunu bulunmaktadır. ${ }^{23}$ Öncelikle, söz konusu sıralama akademisyenlerin kitaplarını ve WoS'ta taranan dergilerin dışında kalan dergilerde yayımlanan makalelerini hesaba katmadığı ${ }^{24}$ gibi

19 ÖSYM, 2018 Merkezi Yerleştirme İle Öğrenci Alan Yükseköğretim Lisans Programları, https://dokuman.osym.gov. tr/pdfdokuman/2018/YKS/YER/Tablo4MinMax_31082018.pdf (Erişim Tarihi 25 Mart 2019) Parantez içindeki rakamlar taban puanları göstermektedir. Vakıf üniversitelerinin tam burslu puanları esas alınmıştır.

20 http://ulakbim.tubitak.gov.tr/sites/images/Ulakbim/uluslararasi_iliskiler.pdf (Erişim Tarihi: 17 Kasım 2018) Parantez içindeki rakamlar toplam SSCI yayınlarını göstermektedir.

21 “Uİ okumak isteyen lisans öğrencileri için Türkiye'deki en iyi 5 üniversite hangileridir” sorusuna verilen cevapların oranına göre bir sıralama yapılmışır. Parantez içindeki rakamlar ankete katılanların ilgili bölüme oy verme oranını göstermektedir. Bkz. Mustafa Aydın et al., “Türkiye’de Uluslararası İlişkiler Akademisyenleri ve Alana Yönelik Yaklaşımları Üzerine Bir İnceleme: TRIP 2014 Sonuçları”, Uluslararası İlişkiler, Cilt 12, No 48, 2016, ss. 3-35; Anket verilerini bizimle paylaşan makalenin yazarlarına teşekkür ediyoruz.

22 Örneğin bkz. Arthur H. Miller et al., "Department Rankings: An Alternative Approach”, PS: Political Science and Politics Cilt 29 No 4, 1996, ss. 704-728.

23 Bu iki temel sorunu bertaraf etmek için ABD'deki Uİ akademisyenlerinin tüm çalışmalarını, aldıkları atıfları göz ardı ederek hesaba katan ve bunların toplamı üzerinden sıralama yapan bazı çalışmalar mevcuttur. Bkz. James McCormick ve Tom Rice, "Graduate Training and Research Productivity in the 1990's: A Look at Who Publishes", PS: Political Science and Politics, Cilt 34, No 3, 2001, s. 675-680. Türkiye özelinde ise benzer bir çalışma mevcut değildir.

24 Hannah June Kim ve Bernard Grofman, “The Political Science 400: With Citation Counts by Cohort, Gender, and Subfield”, PS: Political Science \& Politics, Cilt 52, No 2, 2019, s. 1-16 
bu iki kategorideki çalışmalarda akademisyenlere verilen atıfları da değerlendirmeye almamaktadır. $\mathrm{Bu}$ ölçme biçiminin nitelikli yayınları önemli ölçüde kapsamak gibi bir özelliği olsa da, örneğin prestijli uluslararası yayınevlerinden çıkan kitapları dikkate almamak gibi ciddi bir eksikliği vardır. İkinci olarak, WoS Türkçe yayınları tarama konusunda çok sınılı veriye sahiptir ve bu nedenle hem Türkçe yayınları hem de bu yayınlara Türkçe literatürde verilen atıfları kapsamamaktadır. Bu eksiklik 2015 yllından itibaren The Emerging Sources Citation Index (ESCI) uygulaması ile kısmen giderilmiş olsa da, ${ }^{25}$ WoS hala Türkçe yayınlar konusunda çok yetersiz veriye sahiptir.

WoS verilerinin sınırlı sayıda akademik çalışmayı kapsaması araştırmacıları Uİ bölüm ve akademisyenlerinin akademik başarı sıralamasını yapma noktasında daha kapsayıcı olan GS verilerini kullanmaya yöneltmiştir. Örneğin, Bernard Grofman ve arkadaşları daha önce SSCI verilerinden hareketle $A B D$ 'deki Siyaset Bilimi bölüm ve akademisyenlerine ilişkin yaptıkları çalışmayı ${ }^{26}$ güncelleyerek GS verileri üzerinden yeniden yayımlamıştır. ${ }^{27}$ Fakat Türkiye' de GS verileri üzerinden özellikle Uİ disiplini için benzer bir çalışma yapılmamıştır. Elinizdeki çalışma bu eksikliği gidermeyi amaçlamaktadır. Ayrıca, SSCI verilerini GS verilerinin nitelik ölçüp ölçmediğini test etmek için kullanması nedeniyle mevcut çalışma, SSCI verileri üzerinden sıralama işlemini Uİ çalışan akademisyenler için yapan ilk sistematik çalışma olma özelliğine de sahiptir.

\section{Google Scholar'dan Veri Toplamak}

İnternet servisleri ve ürünleri konusunda hizmet veren $\mathrm{ABD}$ kökenli bir teknoloji firması olan Google, akademisyenlere kendi Akademik (Scholar) sayfalarını kurma imkanı sağlamaktadır. Her akademisyen kendisi için bir hesap açıp GS’nin taradığı ve atıflarını hesapladığı yayınlarını sayfalarına ekleyerek bir GS sayfası oluşturabilmektedir. Ortaya çıkan bu sayfa ilgili akademisyenin toplam atıflarını ve son beş yıldaki atıflarını ayrı ayrı hesaplayarak ilgili akademisyenin atıf alma kapasitesini ortaya koymaktadır. Akademisyenlerin çalışma konularını belirtmeleri halinde ise GS benzer konuda çalışan akademisyenleri en çok atıf alandan en düşük atıf alana göre sıralamaktadır. Örneğin, bir akademisyen kendi sayfasını oluştururken, çalışma alanlarından birine "Türk Dış Politikası” yazmış ise, buna tıklayan kullanıcılar ilgili konuda çalışan tüm akademisyenleri bir arada gördüğü gibi, en çok atıf alanları ilk sırada inceleme imkanına sahip olmaktadır.

$\mathrm{Bu}$ yöntem, yani GS’nin akademisyenlere kendi hesaplarını oluşturma imkanı vermesi, veri toplanmasında iki temel sorun ortaya çıkarmaktadır. İlk olarak bütün akademisyenler kendi sayfalarını oluşturmadığı için mevcut hesaplar üzerinden yapılacak bir sınıflandırmanın çok sayıda akademisyeni dışarıda bırakmak gibi ciddi bir probleme neden olmasıdır. İkinci olarak, kendi sayfalarını oluşturan akademisyenler yayınları ile ilgili olarak sehven yanlış veri girebilmektedirler. Örneğin bir akademisyenin kendisinin olmayan bir yayını sayfasına eklemesi mümkündür. Yine benzer şekilde, akademisyenler, Türkçe'ye çevirdikleri çalışmaları da kendi telif eserleri gibi GS sayfalarına ekleme imkanına sahiptirler. Dolayısıyla GS üzerinden veri toplayan bir araştırmacı, ancak bu iki problemden kaynaklanan hataları minimum düzeye indirdiği sürece sağlıklı verilere ulaşabilmektedir.

$25 \mathrm{Bu}$ çalışmada WoS makale sayısı verilerinde sadece SSCI makaleler kullanılmıştır. WoS, SSCI makalelere ESCI dergilerde verilen atıfları da hesapladığı için Kasım 2018 tarihi itibariyle WoS sistemine dahil olan ESCI dergilerde SSCI makalelere verilen atıflar hesaplamaya dahil olmuştur.

26 Masuoka et al., "The Political Science 400".

27 Kim ve Grofman, "The Political Science 400". 
Bu hata kaynaklarından ilkini gidermek için iki aşamalı bir çalışma gerekmektedir. İlk aşamada yapılması gereken, Türkiye genelindeki tüm bölümleri ve bu bölümlerdeki tüm öğretim elemanlarını listeledikten sonra, bu öğretim üyelerinden GS sayfası olmayanları tespit etmektir. İkinci aşama, sayfası olmayan her bir akademisyen için GS verilerinin toplanması işleminden oluşmaktadır. $\mathrm{Bu}$ çalışmada söz konusu verilerin toplanmasında şöyle bir süreç izlenmiştir. İlk olarak, $\mathrm{X}$ adı ile bir GS hesabı açılmış, daha sonra her bir akademisyen için bazı anahtar kelimeler ile toplanan veriler bu hesaba eklenmiştir. Arama için ilk olarak örneğin, author: "Ad Soyad" şeklinde bir anahtar kelime kullanılmış, ardından gözden kaçanları tespit etmek için author:Ad author:Soyad şeklinde bir arama yapılmıştır. Aynı isme sahip akademisyenleri elemek için author: "Ad Soyad" Üniversite ve author: "Ad Soyad" Konu gibi akademisyenin kurumu veya çalıştığı konularda bir anahtar kelime eklenerek arama yapılmıştır. Bu yöntemle oluşturulan GS sayfasından hem toplam atıflar hem de son beş yıldaki atıf sayısı elde edilmiştir. X isimli GS hesabından taraması yapılan isim için gerekli veriler alındıktan sonra, bu hesaptaki tüm veriler silinerek bir başka akademisyen için aynı yöntemle veriler toplanmıştır. ${ }^{28}$

GS hesabı olmayan akademisyenlerin verilerinin toplanmasında karşılaşılan bir başka önemli sorun $\mathrm{da}$, soy isim farklllkkları ve benzerlikleridir. Özellikle kadın akademisyenler için evlilik ve boşanma sonucu değişen soy isimler, GS aramasında bu akademisyenler ile ilgili verilere ulaşılmasını zorlaştırmaktadır. Benzer sorun aynı isim ve soy isim kombinasyonuna sahip kadın ve erkek akademisyenlerin verileri için de söz konusudur. Hakkında veri toplanan Uİ akademisyenlerinin verileri, yazar anahtar kelimeleri ile yapılan aramalarda aynı soy isme sahip farklı alanlarda (kamu yönetimi, tarih gibi) çalışan akademisyenlerin verileri ile karışmaktadır. Bu sorunu çözmek için, akademisyenlerin kendi web sayfalarında sundukları özgeçmiş ve yayın listeleri kontrol edilmiştir. Bu kontrol yoluyla farklı soy isimle yaptıkları yayınlar, tespit edilenler, ilgili akademisyenin verilerinin toplandığı X isimli GS hesabına eklenmiş veya soy isim benzerliği nedeniyle dahil edilen veriler bu hesaptan çıkartılmıştır.

İkinci problemi, yani yanlış veri girilerek oluşturulmuş hesaplar sorununu, çözmek için ise ilgili akademisyenin sayfasında iki filtre kullanılmıştır. Birincisi, akademisyenin sayfasında bulunan yayınlarda ilgili akademisyen yazar olarak gözükmüyorsa, bunlar hesaplamadan çıarılmıştır. İkincisi, ilgili akademisyen benzer isme sahip başka akademisyenin yayınlarını da sayfasına eklemişse bunlar da hesaplamanın dışında bırakılmıştır. Mevcut hesaplardaki hatalar istatistiki sonuçları etkilemeyecek ölçüde az ise (+-5), ilgili hesabın verileri ile oynanmamıştır. Yanlış veri girilmesi sonuçları ciddi ölçüde etkiliyorsa, mevcut GS hesabından farklı olarak ilgili akademisyenin verileri GS sayfası olmayanlar gibi yeniden hesaplanmıştır. ${ }^{29}$ Son olarak, GS verileri zamanla değiştiği için daha önce verisi çekilen akademisyen ile daha sonra verisi çekilen akademisyen arasında bir adaletsizlik olmaması için tüm veriler 26 Kasım ve 3 Aralık 2018 tarihleri arasındaki bir hafta içinde toplanmıştır. ${ }^{30}$

\section{Google Scholar Verilerinin Görmedikleri}

GS atıf verileri üzerinden yapılacak bir değerlendirmenin altı temel sorunu bulunmaktadır. Birincisi, ilgili bölümlerde hoca-öğrenci oranındaki farklılık akademisyenlerin yayın yapma performanslarını önemli ölçüde etkilemektedir. ${ }^{31}$ Ders yükü çok daha fazla olan bölümlerde istihdam edilen öğretim üyelerinin yayın yapma imkanları ders yükü düşük olanlara göre çok daha kısıtlıdır. Fakat GS

28 Bu yöntemin bir benzeri için bkz. Peress, Measuring the Research Productivity, s. 313.

29 Bu konuda bkz. Peress, Measuring the Research Productivity, s. 313.

30 Veri toplama işlemini büyük ölçüde makalenin yazarlarından Filiz Cicioğlu ve Duygu Kalkan yapmıştır.

31 Bkz. William G. Tierney, (ed.) Faculty Productivity: Facts, Fictions And Issues, New York, Routledge, 1999. 
verileri üzerinden yapılan değerlendirme her iki kategorideki öğretim üyelerinin koşullarını eşit varsaymaktadır. İkincisi, bir çalışmanın aldığı atıflar ile onun kalitesi arasındaki ilişkinin doğru orantılı olup olmadığı ile ilgilidir. Belli bir konunun popüler olması o konuda yazılmış makalelerin daha çok atıf almasını sağlarken, çok daha nitelikli platformda yayımlanan bir başka makale konusu popüler olmaması nedeniyle çok daha az atıf alabilmektedir. ${ }^{32}$ Örneğin, tarih temalı akademik makaleler ile güncel sorunlara odaklanan akademik çalışmaların atıfları arasındaki fark bunu çok net bir şekilde göstermektedir. Üçüncü olarak, GS bir ve çok yazarlı makale arasında ayrımına imkan sağlamamaktadır. Tek yazarlı makale sadece bir yazarın atıflarını beslerken, çok yazarlı makalelerde atıflar tüm yazarlara toplam olarak gitmektedir. Yazar sayısı arttıkça bu dengesiz durumun etkisi büyümektedir. Teknik olarak WoS atıflarında bunu temizlemenin ve atıfların ağırlığını yazar sayısına göre dağıtmanın üzerinde uzlaşılmış bir yöntemi yoktur. ${ }^{33}$

Dördüncüsü, GS sadece çevrimiçi (online) ortama aktarılmış akademik çalışmalar üzerinden veri oluşturmaktadır. ${ }^{34}$ Bu nedenle, Türkçe yayımlanmış kitaplar ve raporlar ile bu yayınlarda diğer çalışmalara verilmiş atıflar hesaplanamamaktadır. Çevrimiçi akademik platformu olan dergi ve yayınevlerinde yayın yapan akademisyenler GS verileri üzerinden yapılan bu hesaplama sisteminde avantajlı bir konuma sahip olmaktadır. GS bu sorunu, çevrimiçi hali bulunmayan yayınlara çevrimiçi yayınlarda verilen atıfları hesaplamalarına katarak önemli ölçüde hafifletse de, bu tür yayınlarda başka çalışmalara verilen atıfları veri olarak alamamaktadır. Beşinci olarak kişisel bağlantılar, benzer kurumsal yapılara ait olma, ideolojik kamplaşma, cinsiyet ve merkez-taşra ayrımı gibi çalışmanın niteliğinden bağımsız olarak atıf almayı etkileyen sosyal dinamiklerden bahsedilebilir. ${ }^{35}$ Özellikle politik kamplaşmanın çok yüksek olduğu Türkiye gibi ülkelerde bu sosyal dinamikler atıf sayılarını önemli ölçüde etkileyebilmektedir. ${ }^{36}$ Altıncı ve son olarak, kendi kendine atıfların (self-citation) genel atıf performansını etkilemesi noktasında Google Scholar güvenilir bir eleme imkanı sunmaktan uzaktır. ${ }^{37}$ GS ile karşılaştırıldığında WoS’un en önemli avantajı kendi kendine atıfları ayrı bir şekilde hesaplama imkanı sunmasıdır. ${ }^{38}$

Çözülmesi pek mümkün olmayan bu altı probleme ek olarak GS verileri farklı verileri analize dahil etmek yoluyla çözülebilecek iki problem daha içermektedir. Birincisi, alanda yeni olan akademisyenler ile alanda çok daha eski olan akademisyenlerin aynı kriterler ile değerlendirilmesi sağlıklı bir sonuç

32 Bazı konularda yapılan çalışmaların daha fazla atıf alma potansiyeli konusunda bkz. Éric Montpetit, et al., "What Does It Take For A Canadian Political Scientist To Be Cited?”, Social Science Quarterly, Cilt 89, No 3, 2008, ss. 802-816.

33 Üstelik daha fazla yazarlı metinler daha az yazarlı metinlere göre atıf alma konusunda daha avantajllar. Bkz. Vincent Larivière et al., "Team Size Matters: Collaboration and Scientific Impact Since 1900”, Journal of the Association for Information Science and Technology, Cilt 66, No 7, 2015, ss. 1323-1332.

34 Bu ayrıntıyı dikkatimize sunan Uluslararası İlişkiler Dergisi hakemlerine teşekkür ederiz.

35 Kişisel ilişkilerin etkisi için örneğin bkz. James H. Fowler et al., "Social Networks in Political Science: Hiring And Placement of Ph.Ds, 1960-2002”, PS: Political Science \& Politics, Cilt 40, No 4, 2007, ss. 729-739. Cinsiyet etkisi için bkz. Dawn Langan Teele ve Kathleen Thelen, “Gender in The Journals: Publication Patterns in Political Science”, PS: Political Science \& Politics Cilt 50, No 2, 2017, ss. 433-447.

36 Türkiye Uİ disiplini içinde sosyal dinamiklerin etkisi için bkz. Ersel Aydınlı ve Julie Mathews, "Periphery Theorising For A Truly Internationalised Discipline: Spinning IR Theory Out Of Anatolia”, Review of International Studies, Cilt 34, No 4, 2008, ss. 693-712.

37 Christoph Bartneck ve Servaas Kokkelmans, "Detecting h-index Manipulation Through Self-citation Analysis", Scientometrics, Cilt 87, No 1, 2011, ss. 85-98

38 Uİ Dergisi hakemlerinin önerisi doğrultusunda Tablo 3'teki SSCI Toplam Atıf verilerini kendi kendine atıf bağlamında incelediğimizde buradaki 40 akademisyen içinde en yüksek kendi kendine atıf oranı yüzde 28 çıkmıştır. 40 akademisyenden sadece 2'sinin kendi kendine atıf oranı yüzde 20'nin üzerinde çıkarken, 7 akademisyenin oranı yüzde 10-20 arasında çıkmıştır. Kendi kendine atfın toplam atıflara oranı, dünya genelinde yüzde 36 olduğu göz önüne alınırsa, en azından SSCI toplam atıfta ilk 40’a giren akademisyenlerde WoS özelinde bu oranın yüksek olmadığı söylenebilir. Bkz. Bartneck ve Kokkelmans, Detecting h-index Manipulation, s.86 
vermeyecektir. ${ }^{39} \mathrm{Bu}$ sorunu göreli olarak ortadan kaldırmak için GS son beş yıllık atıf oranlarına ayrı bir kategori olarak yer verse de, bu durum temel meseleyi çözmemektedir. Alanda yeni olan akademisyenler için bilinirlik çok daha az olacağı için atıf alma oranları bakımından alanın eski isimlerine göre dezavantajlı konumda oldukları söylenebilir. Bu da atıf sayıları üzerinden yapılan nitelik sıralamasının, alanın eskilerini ayrıcalıklı hale getirmesi gibi bir durumla sonuçlanmasına neden olmaktadır. Dolayısıyla, alanda yeni olmaktan kaynaklanan dezavantajlı durumu gidermek için GS’nin sağlamadığı farklı bir veriye ihtiyaç vardır. ${ }^{40} \mathrm{Bu}$ çerçevede, bu çalışmada akademisyenlerin doktora aldıkları yıllar tespit edildikten sonra Kim ve Grofman'ın yaptığı gibi göreli olarak genç olanların ayıı bir sıralamaya tabi tutulması yoluyla kıdem farkından kaynaklanan sorun önemli ölçüde giderilmeye çalışılmıştır. ${ }^{41}$

İkinciolarak, GSverilerineençokyapılan eleştirinitelikliveniteliksizyayın/atıfayrımıyapmaması şeklindedir. Bu sebeple GS üzerinden yapılacak sıralamaları kontrol amacıyla, akademisyenlerin SSCI makale sayısı ve bu makalelere verilen atıf sayıları gibi iki veri üzerinden yapılan sıralamalar oluşturulmuştur. Bu verilerden oluşturulan sıralamalar, GS verilerinden oluşturulan sıralamanın yanında verilecek ve okuyucuya genel atıflar üzerinden yapılan sıralama ile daha nitelikli olduğu kabul edilen SSCI’lı yayın ve atıflar üzerinden yapılan sıralamayı karşılaştırma imkanı sunulmuştur. Fakat bu çalışmanın önceliği, GS verileri üzerinden sıralamaları ortaya koymaktır. SSCI nitelik ayrımına imkan sağlasa da, örneğin Türkçe yayın yapmaya ve ders kitabı yazmaya öncelik veren akademisyenler hakkında herhangi bir veriye sahip değildir. SSCI'ın aksine GS bütün akademisyenlere ve onların bir şekilde atıf almış bütün çalışmalarına dair mevcut en kapsamlı veriyi sağlamaktadır.

\section{Verileri Analiz Etmek}

$\mathrm{Bu}$ çalışmada 132 farklı bölümden 1053 akademisyenin (doktorasını tamamlamamış Araştırma

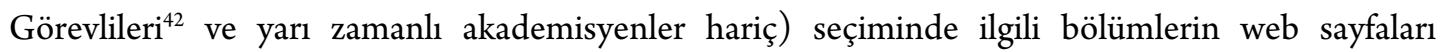
kullanılmıştır. Bölüm web sayfalarındaki veriler daha güncel olan Yüksek Öğretim Kurumu (YÖK) tarafindan hazırlanan akademisyenler veri tabanındaki bilgiler ile de kontrol edilmiştir. ${ }^{43} \mathrm{Bu}$ iki kaynaktan derlenerek tespit edilen akademisyenlerin yukarıda açıklanan yöntemler kullanılarak atıf sayısı verileri toplanmıştır. Verilerin toplandığı Kasım-Aralık 2018 tarihi göz önüne alındığında 419 akademisyen kendi GS sayfalarını hazırlamıştır. ${ }^{44} 634$ akademisyen için ise $\mathrm{X}$ adı altında oluşturulan hesap yoluyla GS verileri tek tek hesaplanmıştır. Bu akademisyen sayfalarından elde edilen veriler akademisyenler ve bölümler olmak üzere 2 farklı kategori altında analiz edilmiştir.

Birinci kategoride, Türkiye'deki Uİ ve SBUİ bölümlerinde istihdam edilen akademisyenler yaptıkları çalışmalara verilen atıflar üzerinden genel bir sıralamaya tabi tutulmuştur. Bu şekilde ortaya çıkan listede Uİ alanı dışında, Tarih, Siyaset Bilimi, Sosyoloji gibi konularda çalışan ama ilgili bölüm

39 Masuoka et al., “The Political Science 400”, s. 1.

$40 \mathrm{Bu}$ ayrıntıyı dikkatimize sunan Uluslararası İlişkiler Dergisi hakemlerine teşekkür ederiz.

41 Kim ve Grofman, “The Political Science 400”, s. 1.

42 Vakıf üniversitelerinde Araştırma Görevlileri genellikle geçici bir kadro olarak istihdam edilmekte, devlet üniversitelerinde ise özellikle 35. Madde kapsamında istihdam edilenler aynı anda farklı üniversitelerin web sayfalarında gözükmektedirler. Bu durum özellikle bölüm karşılaştırmalarında istatistiki sorunlara neden olmaktadır.

$43 \mathrm{Bu}$ veri tabanı için bkz. "YÖK Akademik: Yükseköğretim Akademik Arama”, https://akademik.yok.gov.tr/ AkademikArama/ (Erişim Tarihi 25 Kasım 2018)

44 Çalı̧̧mada verilen tablolarda verilerin toplandığı tarihte GS sayfası olan isimler italik olarak yazılmıştır. Bu tarihten sonra GS sayfalarını oluşturan ve silen akademisyenlerin olabileceğini okuyucu göz önünde tutmalıdır. Bununla ilgili Sakarya Üniversitesi Etik Kurulu’ndan uygunluk raporu alınmıştır. 
kadrosunda bulunan isimler de mevcuttur. Dolayısıyla, söz konusu listeye alternatif olarak, temel çalışma konusu Uİ disiplini içinde yer alan akademisyenler için ayrı bir liste hazırlanmıştır. ${ }^{45}$ Genel atıf toplamları üzerinden hazırlanan bu sıralamaya paralel şekilde, akademisyenlerin yakın dönemdeki atıf alma performanslarını ölçmek amacıyla son beş yılda aldıkları atıflara göre de iki ayrı (ilgili bölümde istihdam edilenler ve sadece uluslararası ilişkiler çalışanlar) sıralama daha yapılmıştır.

GS verileri üzerinden yapılan bu dört sıralamanın belirli bir nitelik göstergesi olup olmadığının test edilmesi noktasında SSCI yayın ve atıf verileri kontrol değişkeni olarak devreye sokulmuştur. Akademisyenlerin toplam SSCI yayınları ve bu yayınlara WoS sistemi içinde taranan dergilerde yapılan atıflar hesaplanarak, yeni karşılaştırma listeleri oluşturulmuştur. Fakat bu veriler üzerinden son 5 yıllık performansı ayırmak WoS tarama kriterleri ile mümkün değildir. Dolayısıyla burada iki liste kategorisi ortaya çıkmıştır: 1) Uİ ve SBUİ bölümlerinde istihdam edilen tüm akademisyenlerin SSCI yayınları ve atıfları üzerinden sıralanması; 2) İlgili bölümlerde bulunan ve çalışma konusu uluslararası ilişkiler olan tüm akademisyenlerin SSCI yayın sayıları ve atıfları üzerinden sıralanması.

Akademisyenler arasında kıdemden kaynaklanan avantaj ve dezavantajın etkisini minimuma indirmek için yeni bir tablo daha oluşturulmuştur. Akademik etkileri ölçülen akademisyenlerin doktora aldıkları yıllar dikkate alınarak oluşturulan bu yeni tabloda, GS ve SSCI verileri diğer iki tabloda olduğu gibi gösterilmiştir. Doktora alınan tarihlerin beş yıllık dönemlere bölündügü bu tabloda sıralama önceliği doktorasını en geç tarih gurubunda (2013-2017) alanlara verilmiştir. Yine bu tablo (Tablo 2'de olduğu gibi) çalışma alanı uluslararası ilişkiler olan isimleri değerlendirmeye $\mathrm{alm}^{4 s^{46}}$ ve tabloda bu isimlerin verileri üzerinden bir ölçüm yapılmıştır.

İkinci kategoride, atıf ve yayın sayıları saptanan akademisyenlerin mensubu oldukları bölümlere göre tasnif edilmesi ile Türkiye genelindeki Uİ ve SBUİ bölümlerinin sıralaması ortaya konulmuştur. İlgili bölümde istihdam edilen tüm akademisyenlerin atıflarının 'Google Scholar genel' ve 'Google Scholar son 5 yıl' ayrı şekilde toplanması ile elde edilen rakamlar üzerinden bölümlerin sıralanması yapılmıştır. Bu şekilde, iki kategorideki performansa göre Türkiye'deki Uİ bölümleri sıralaması elde edilmiştir. SSCI kontrol değişkeni burada da uygulanmış ve bölümler toplam SSCI yayını ve bu yayınlara alınan atıflar üzerinden yeniden sıralanmıştır. Elde edilen bu dört sıralama daha fazla öğretim üyesi istihdam eden bölümleri avantajl kılacağından ilgili rakamların bölümdeki öğretim üyesi sayısına bölünmesi ile elde edilen sonuçlarla yeni bir sıralama tablosu daha yapılmıştır.

\section{Sonuçlar}

Aşağıda 5 farklı tablo bulunmaktadır. Tablo 2, Uİ ve SBUİ bölümlerinde istihdam edilen tüm akademisyenler için GS ve SSCI sıralamalarını göstermektedir. Tablo 3 UI çalışan akademisyenler

45 Bu listenin hazırlanmasında verileri derlenen akademisyenlerin Uluslararası İlişkiler disiplinin alt dalları olan Uluslararası İlişkiler Teorileri, Dış Politika Analizi, Siyasi Tarih, Bölge Çalışmaları, Türk Dış Politikası, Uluslararası Hukuk, Uluslararası Politik Ekonomi ve Terörizm ve Güvenlik gibi alanlarda çalışmaları olup olmadıkları dikkate alınmıştır. Bu gibi alanlarda çalışma yapmayanlar Uİ çalışan akademisyenler listesinin dışında bırakılmıştır. Uİ çalışmaları yapmış bir akademisyenin farklı bir temada çalışmaları olması, örneğin politik ekonomi gibi, onun disiplin dışından aldığı atıfları artırsa da, bu durumda olan akademisyenler listeden çıkartılmamıştır. Uİ temel çalışma alanları ile ilgili bkz. Mustafa Aydın, ve Korhan Yazgan, “Türkiye’de Uluslararası İlişkiler Akademisyenleri Eğitim: Araştırma ve Uluslararası Politika Anketi - 2011”, Uluslararası İlişkiler, Cilt 9, No 36, 2013, s. 3-44, s. 16 ve 30 nolu dipnot.

46 Uİ ve SBUİ bölümlerinden istihdam edilmeyip, çalışma alanı uluslararası ilişkiler olan isimler hesaplamaya dahil edilmemiştir. 
için GS ve SSCI sıralamalarını, Tablo 4 ise, genç akademisyenlerin kıdemli olanlara kıyasla atıf alma noktasındaki dezavantajını ortadan kaldırmak amacıyla doktora alma dönemlerine göre atıf performanslarını vermektedir. Tablo 5’te Uİ ve SBUI bölümleri için GS ve SSCI sıralamaları mevcuttur. Tablo 6'da ise, GS ve SSCI'daki atıf ve yayın sayılarının ilgili bölümlerde bulunan öğretim üyesi sayısına bölünmesi ile ortaya çıkan bölüm sıralamaları gösterilmiştir. ${ }^{47}$

Tablo 2: Uİ ve SBUİ Bölümlerine Kayıtlı Tüm Akademisyenler için Google Scholar ve SSCI Sıralaması

\begin{tabular}{|c|c|c|c|c|}
\hline & \multicolumn{2}{|c|}{ Google Scholar (GS) Atıfları } & \multicolumn{2}{|c|}{ SSCI Verileri } \\
\hline & GS Genel Atıf & GS 5-Y1l Atıf & Makale Sayısı & Toplam Atıf \\
\hline 1 & Ziya Öniş (8083) & Ziya Öniş (3654) & Ziya Öniş (40) & Ziya Öniş (925) \\
\hline 2 & Feroz Ahmad (4400) & Ahmet İçduygu (2312) & Giray Gözgör (37) & Koray Çalışkan (563) \\
\hline 3 & Fuat Keyman (4234) & Fuat Keyman (2157) & Bülent Aras (36) & Ptnar Bilgin (376) \\
\hline 4 & Ahmet İçduygu (3841) & Feroz Ahmad (1846) & Meltem Müftüler-Baç (2197) (25) & Bahar Rumelili (327) \\
\hline 5 & Ali Çarkoğlu (3435) & Ali Çarkoğlu (1729) & Ayhan Kaya (23) & Resul Yalçın (292) \\
\hline 6 & Bülent Aras (2613) & Pinar Bilgin (1506) & M. Hüs. Bilgin (23) & Fuat Keyman (274) \\
\hline 7 & Pinar Bilgin (2574) & Bülent Aras (1371) & Fuat Keyman (21) & André Kaiser (257) \\
\hline 8 & Yeşim Arat (2357) & Koray Çalışkan (1296) & Pinar Bilgin (19) & Ali Çarkoğlu (256) \\
\hline 9 & E. Kalaycioğlu (2334) & Ayhan Kaya (1199) & Ersel Aydınlı (19) & Meltem Müftüler-Baç (240) \\
\hline 10 & Meltem Müftüler-Baç (2197) & Yeşim Arat (1163) & Ali Çarkoğlu (18) & Murat Somer (224) \\
\hline 11 & Ayhan Kaya (1922) & E. Kalaycıoğlu (1113) & Bahar Rumelili (18) & R. Karakaya Polat (212) \\
\hline 12 & André Kaiser (1860) & Meltem Müftüler-Baç (1087) & André Kaiser (16) & Bülent Aras (187) \\
\hline 13 & Koray Çalışkan (1675) & Bahar Rumelili (860) & Cengiz Erişen (16) & Ersel Aydınlı (160) \\
\hline 14 & Mustafa Aydın (1592) & André Kaiser (754) & Murat Somer (15) & E. Kalaycıŏlu (156) \\
\hline 15 & Bahar Rumelili (1453) & Mustafa Aydın (747) & Tarık Oğuzlu (14) & Caner Bakır (152) \\
\hline 16 & Izak Atiyas (1344) & M. Altunışık (746) & M. Kibaroğlu (14) & Şuhnaz Yilmaz (142) \\
\hline 17 & M. Altunışık (1278) & Ömer Çaha (722) & Ç. Kentmen (14) & Tarık Oğuzlu (128) \\
\hline 18 & Yllmaz Esmer (1266) & Senem Düzgit (676) & Ahmet İçduygu (13) & Aylin Güney (128) \\
\hline 19 & İlter Turan (1216) & Resul Yalçın (555) & Mustafa Aydın (13) & Yunus Kaya (124) \\
\hline 20 & Senem Düzgit (1134) & Tarık Oğuzlu (551) & Şuhnaz Yilmaz (13) & Fougner Tore (122) \\
\hline 21 & Ömer Çaha (1074) & R. Karakaya Polat (548) & Caner Bakır (13) & Giray Gözgör (116) \\
\hline 22 & İhsan Dağı (1059) & Tayyar Arı (543) & E. Kalaycıoğlu (12) & Ayhan Kaya (109) \\
\hline 23 & Norman Stone (1050) & G. Çetinsaya (537) & M. Altunışık (11) & Menderes Çınar (104) \\
\hline 24 & Tayyar Arı (1025) & Mehmet Ípşirli (531) & A. Betül Çelik (11) & Ahmet $\dot{I}_{c ̧} d u y g u$ (98) \\
\hline 25 & R. Karakaya Polat (934) & H. D. Yükseker (526) & Emel P. Dal (11) & M. Altunışık (94) \\
\hline 26 & H.D. Yükseker (879) & Yilmaz Esmer (516) & Selim E. Aytaç (11) & N. Ali Özcan (92) \\
\hline 27 & Tarık Oğuzlu (864) & İhsan Dağı (505) & M. Biresselioğlu (11) & Cengiz Erişen (89) \\
\hline 28 & Menderes Çınar (838) & Z. Gambetti (504) & Senem Düzgit (10) & Senem Düzgit (88) \\
\hline 29 & A. Kibaroğlu (835) & Murat Somer (495) & Şener Aktürk (10) & M. Hüs. Bilgin (84) \\
\hline 30 & Ersel Aydınlı (833) & Menderes Çınar (466) & Aylin Güney (10) & H. D. Yükseker (80) \\
\hline 31 & Murat Somer (803) & Ali Balci (460) & D. Tsarouhas (10) & Alper Kaliber (78) \\
\hline 32 & G. Çetinsaya (789) & İlter Turan (459) & Özgür Kıbrıs (10) & Ç. Kentmen (73) \\
\hline 33 & Mehmet Ípşirli (748) & Ersel Aydınlı (451) & R. Karakaya Polat (9) & Reşat Bayer (73) \\
\hline 34 & M. Kibaroğlu (727) & A. Kibaroğlu (438) & N. Ali Özcan (9) & Şener Aktürk (72) \\
\hline 35 & Resul Yalçın (717) & Izak Atiyas (433) & Emre İşeri (9) & Yeşim Arat (71) \\
\hline 36 & Serpil Çakır (704) & Şener Aktürk (420) & A. Buergin (9) & Berk Esen (68) \\
\hline 37 & Mine Eder (694) & Giray Gözgör (416) & Özlem Altan (9) & M. Kibaroğlu (67) \\
\hline 38 & A. Betül Çelik (635) & A. Betül Çelik (403) & Necati Polat (9) & A. Betül Çelik (64) \\
\hline 39 & Z. Gambetti (625) & Murat Erdoğan (380) & M. E. Hatipoğlu (9) & Tanel Demirel (62) \\
\hline 40 & Aylin Güney (607) & İsmail Kara (379) & İnci Gümüş (9) & Selim E. Aytaç (58) \\
\hline
\end{tabular}

47 Bu çalışma için toplanan tüm veriler 99 Excel sayfası uzunluğundan olduğu için tamamının tablolar halinde bu makaleye dahil edilmesi mümkün değildir. Veri seti için bkz. https://dataverse.harvard.edu/dataverse/uidergisi 
Tablo 3: Uİ Çalışan Akademisynler için Google Scholar ve SSCI Sıralaması

\begin{tabular}{|c|c|c|c|c|}
\hline & \multicolumn{2}{|l|}{ Google Scholar (GS) Atıfları } & \multicolumn{2}{|l|}{ SSCI Verileri } \\
\hline & GS Genel Atıf & GS 5-Yil Atıf & Makale Sayısı & Toplam Atıf \\
\hline 1 & Ziya Öniş (8083) & Ziya Öniş (3654) & Ziya Öniş (40) & Ziya Öniş (925) \\
\hline 2 & Fuat Keyman (4234) & Fuat Keyman (2157) & Bülent Aras (36) & Ptnar Bilgin (376) \\
\hline 3 & Bülent Aras (2613) & Pinar Bilgin (1506) & Meltem Müftüler-Baç (25) & Bahar Rumelili (327) \\
\hline 4 & Ptnar Bilgin (2574) & Bülent Aras (1371) & Ayhan Kaya (23) & Resul Yalçın (292) \\
\hline 5 & Meltem Müftüler-Baç (2197) & Ayhan Kaya (1199) & Fuat Keyman (21) & Fuat Keyman (274) \\
\hline 6 & Ayhan Kaya (1922) & Meltem Müftüler-Baç (1087) & Ptnar Bilgin (19) & Meltem Müftüler-Baç (240) \\
\hline 7 & Mustafa Aydin (1592) & Bahar Rumelili (860) & Ersel Aydınlı (19) & Murat Somer (224) \\
\hline 8 & Bahar Rumelili (1453) & Mustafa Aydin (747) & Bahar Rumelili (18) & R. Karakaya Polat (212) \\
\hline 9 & M. Altunışık (1278) & M. Altunışık (746) & Cengiz Erişen (16) & Bülent Aras (187) \\
\hline 10 & İlter Turan (1216) & Senem Düzgit (676) & Murat Somer (15) & Ersel Aydınlı (160) \\
\hline 11 & Senem Düzgit (1134) & Resul Yalçın (555) & Tarık Oğuzlu (14) & Caner Bakır (152) \\
\hline 12 & İhsan Dağı (1059) & Tarık Oğuzlu (551) & M. Kibaroğlu (14) & Şuhnaz Yilmaz (142) \\
\hline 13 & Tayyar Art (1025) & R. Karakaya Polat (548) & Ç. Kentmen (14) & Tarık Oğuzlu (128) \\
\hline 14 & R. Karakaya Polat (934) & Tayyar Arı (543) & Mustafa Aydin (13) & Aylin Güney (128) \\
\hline 15 & H. D. Yükseker (879) & G. Çetinsaya (537) & Şuhnaz Yilmaz (13) & Fougner Tore (122) \\
\hline 16 & Tarık Oğuzlu (864) & H. D. Yükseker (526) & Caner Bakır (13) & Ayhan Kaya (109) \\
\hline 17 & A. Kibaroğlu (835) & İhsan Dă̆l (505) & M. Altunışık (11) & M. Altunışık (94) \\
\hline 18 & Ersel Aydınlı (833) & Murat Somer (495) & Emel P. Dal (11) & N. Ali Özcan (92) \\
\hline 19 & Murat Somer (803) & Ali Balct (460) & M. Biresselioğlu (11) & Cengiz Erişen (89) \\
\hline 20 & G. Çetinsaya (789) & İlter Turan (459) & Senem Düzgit (10) & Senem Düzgit (88) \\
\hline 21 & M. Kibaroğlu (727) & Ersel Aydınlı (451) & Şener Aktürk (10) & H. D. Yükseker (80) \\
\hline 22 & Resul Yalçın (717) & A. Kibaroğlu (438) & Aylin Güney (10) & Alper Kaliber (78) \\
\hline 23 & Mine Eder (694) & Şener Aktürk (420) & D. Tsarouhas (10) & Ç. Kentmen (73) \\
\hline 24 & Aylin Güney (607) & Murat Erdoğan (380) & R. Karakaya Polat (9) & Reşat Bayer (73) \\
\hline 25 & Dilek Çınar (597) & Şaban Kardaş (373) & N. Ali Özcan (9) & Şener Aktürk (72) \\
\hline 26 & Çağrı Erhan (588) & Mine Eder (346) & Emre İşeri (9) & Berk Esen (68) \\
\hline 27 & Ali Balcı (582) & Şuhnaz Yilmaz (342) & A. Buergin (9) & M. Kibaroğlu (67) \\
\hline 28 & Birol Akgün (576) & Özlem Tür (337) & Özlem Altan (9) & M. Biresselioğlu (56) \\
\hline 29 & Şaban Kardaş (575) & M. Kibaroğlu (327) & Necati Polat (9) & Özlem Tür (49) \\
\hline 30 & Şuhnaz Yilmaz (561) & Caner Bakır (326) & M. E. Hatipoğlu (9) & D. Tsarouhas (48) \\
\hline 31 & N. Ali Özcan (553) & Birol Akgün (324) & S. Ş. Güner (8) & Talha Köse (46) \\
\hline 32 & Özlem Tür (537) & Çağrı Erhan (307) & Şaban Kardaş (8) & Şaban Kardaş (45) \\
\hline 33 & Şener Aktürk (516) & Mehmet S. Erol (298 & Özlem Tür (8) & Mustafa Aydin (44) \\
\hline 34 & Caner Bakır (510) & Aylin Güney (297) & Reşat Bayer (8) & Özlem Altan (43) \\
\hline 35 & Gencer Özcan (504) & M. Yeşiltaş (294) & S. Güvenç (8) & B. Saatçioğlu (43) \\
\hline 36 & Muhittin Ataman (481) & B. Duran (279) & S. H. Kırımlı (8) & Gözde Yilmaz (43) \\
\hline 37 & H. Kösebalaban (478) & Deniz Sert (278) & Ali Balcı (7) & M. Guida (38) \\
\hline 38 & B. Duran (468) & Muhittin Ataman (273) & Mitat Çelikpala (7) & İhsan Dağı (35) \\
\hline 39 & Beril Dedeoğlu (450) & N. Ali Özcan (272) & Burak B. Özpek (7) & Ali Balcı (34) \\
\hline 40 & Soli Özel (446) & H. Kösebalaban (270) & Asli Ilgit (7) & Deniz Sert (31) \\
\hline
\end{tabular}


Tablo 4: Uİ Çalışan Akademisyenler için Doktora Aldıkları Dönemlere Göre Google Scholar ve SSCI Sıralaması

\begin{tabular}{|c|c|c|c|c|}
\hline & \multicolumn{2}{|c|}{ Google Scholar (GS) Atıfları } & \multicolumn{2}{|l|}{ SSCI Verileri } \\
\hline & GS Genel Atıf & GS 5-Yıl Atıf & Makale Sayısı & Toplam Atıf \\
\hline \multicolumn{5}{|c|}{2013 Sonrasında Doktorasını Alan Akademisyenler } \\
\hline 1 & Berk Esen (182) & Berk Esen (179) & Berk Esen (6) & Berk Esen (68) \\
\hline 2 & Erol Ülker (170) & Erol Ülker (118) & Efe Tokdemir (6) & Tudor A. Onea (25) \\
\hline 3 & S. Barış Gülmez (111) & S. Barış Gülmez (78) & Can Cemgil (5) & Dicle Korkmaz (24) \\
\hline 4 & Emine A. Alagöz (95) & Tudor A. Onea (75) & S. Barış Gülmez (4) & S. Barış Gülmez (20) \\
\hline 5 & Tudor A. Onea (84) & Emine A. Alagöz (74) & Tudor A. Onea (4) & Selma Şekercioğlu (17) \\
\hline 6 & Habibe Özdal (75) & Habibe Özdal (68) & Defne Günay (4) & Sezin İba Gürsoy (14) \\
\hline 7 & Dicle Korkmaz (64) & Dicle Korkmaz (60) & Sedef Turper (4) & Sedef Turper (13) \\
\hline 8 & Muharrem Ekşi (60) & Can Cemgil (57) & Ömer Faruk Örsün (3) & Şirin Duygulu Elcim (13) \\
\hline 9 & Sinan Yildırmaz (60) & Defne Günay (56) & Ömer Aslan (3) & F. Fulya Hisarlıoğlu (12) \\
\hline 10 & Defne Günay (58) & Sedef Turper (48) & Arzu Güler (3) & Eliza Gheorghe (11) \\
\hline \multicolumn{5}{|c|}{ 2008-2012 Yılları Arasında Doktorasını Alan Akademisyenler } \\
\hline 1 & Senem A. Düzgit (1134) & Senem A. Düzgit (676) & Cengiz Erişen (16) & Cengiz Erişen (89) \\
\hline 2 & Ali Balcı (582) & Ali Balcı (460) & Emel P.Dal (11) & Senem Düzgit (88) \\
\hline 3 & Şaban Kardaş (757) & Şener Aktürk (420) & M. Biresselioğlu (11) & Şener Aktürk (72) \\
\hline 4 & Şener Aktürk (516) & Şaban Kardaş (373) & Senem Düzgit (10) & M. Biresselioğlu (56) \\
\hline 5 & A. Akdevelioğlu (442) & Murat Yeşiltaş (294) & Şener Aktürk (10) & Talha Köse (46) \\
\hline 6 & Deniz Sert (340) & Cengiz Erişen (257) & Emre İşeri (9) & Şaban Kardaş (45) \\
\hline 7 & Sinem Açıkmeşe (319) & A. Akdevelioğlu (232) & M. E. Hatipoğlu (9) & B. Saatçioğlu (43) \\
\hline 8 & Murat Yeşiltaş (318) & Talha Köse (205) & Şaban Kardaş (8) & Gözde Yilmaz (43) \\
\hline 9 & Cengiz Erişen (281) & Emel Parlar Dal (205) & Talha Köse (7) & Ali Balci (34) \\
\hline 10 & Emre İşeri (237) & Sinem Açıkmeşe (204) & Burak B. Özpek (7) & Emre İşseri (31) \\
\hline \multicolumn{5}{|c|}{ 2003-2007 Yilları Arasında Doktorasını Alan Akademisyenler } \\
\hline 1 & R. Karakaya Polat (934) & Tarık Oğuzlu (551) & Tarık Oğuzlu (14) & R. Karakaya Polat (212) \\
\hline 2 & Tarık Oğuzlu (864) & R. Karakaya Polat (548) & Çiğdem Kentmen (14) & Caner Bakır (152) \\
\hline 3 & Özlem Tür (537) & Murat Erdoğan (403) & Caner Bakır (13) & Tarık Oğuzlu (128) \\
\hline 4 & Caner Bakır (510) & Caner Bakır (326) & D. Tsarouhas (10) & Reşat Bayer (73) \\
\hline 5 & H. Kösebalaban (478) & Mehmet S. Erol (298) & A. Buergin (9) & Çiğdem Kentmen (73) \\
\hline 6 & Alper Kaliber (422) & Deniz Sert (278) & Özlem Altan (9) & Alper Kaliber (56) \\
\hline 7 & Mehmet S. Erol (406) & Hasan K. Balaban (270) & R. Karakaya Polat (9) & Özlem Tür (49) \\
\hline 8 & Murat Erdoğan (370) & Alper Kaliber (264) & Özlem Tür (8) & D. Tsarouhas (48) \\
\hline 9 & Reşat Bayer (342) & Banu Eligür (242) & S. Güvenç (8) & Özlem Altan (43) \\
\hline 10 & Banu Eligür (308) & Reşat Bayer (238) & Reşat Bayer (8) & M. Guida (38) \\
\hline \multicolumn{5}{|c|}{2003 Öncesinde Doktorasını Alan Akademisyenler } \\
\hline 1 & Ziya Öniş (8083) & Ziya Öniş (3654) & Ziya Öniş (40) & Ziya Öniş (925) \\
\hline 2 & Fuat Keyman (4234) & Fuat Keyman (2157) & Bülent Aras (36) & Pinar Bilgin (376) \\
\hline 3 & Bülent Aras (2613) & Ptnar Bilgin (1506) & Meltem Müftüler-Baç (25) & Bahar Rumelili (327) \\
\hline 4 & Pinar Bilgin (2574) & Bülent Aras (1371) & Ayhan Kaya (23) & Resul Yalçın (292) \\
\hline 5 & Meltem Müftüler-Baç (2197) & Ayhan Kaya (1199) & Fuat Keyman (21) & Fuat Keyman (274) \\
\hline 6 & Ayhan Kaya (1922) & Meltem Müftüler-Baç (1087) & Ptnar Bilgin (19) & Meltem Müftüler-Baç (240) \\
\hline 7 & Mustafa Aydın (1592) & Bahar Rumelili (860) & Ersel Aydınlı (19) & Murat Somer (224) \\
\hline 8 & Bahar Rumelili (1453) & Mustafa Aydin (747) & Bahar Rumelili (18) & Bülent Aras (187) \\
\hline 9 & M. Altunışık (1278) & M. Altunışı (746) & Murat Somer (15) & Ersel Aydınlı (160) \\
\hline 10 & İlter Turan (1216) & Resul Yalçın (555) & M. Kibaroğlu (14) & Şuhnaz Yilmaz (142) \\
\hline
\end{tabular}


Tablo 5: Uİ ve SBUİ Bölümleri için Google Scholar ve SSCI Sıralamaları

\begin{tabular}{|c|c|c|c|c|}
\hline & \multicolumn{2}{|c|}{ Google Scholar (GS) Atıfları } & \multicolumn{2}{|c|}{ SSCI Verileri } \\
\hline & GS Genel Atıf & GS 5-Yıl Atıf & Makale Sayısı & Toplam Atıf \\
\hline $\mathbf{1}$ & Koç Uİ (20297) & Koç Uİ (11077) & Koç Uİ (181) & Koç Uİ (2423) \\
\hline 2 & Sabancı UÇ48 (15561) & Sabancı UÇ (7856) & Sabancı UÇ (155) & Sabancı UÇ (1115) \\
\hline 3 & Boğaziçi SBUİ (7164) & Boğaziçi SBUİ (4166) & Bilkent Uİ (113) & Bilkent Uİ (926) \\
\hline 4 & Bilkent Uì (6364) & Bilkent Uİ (3709) & Bilgi Uİ (75) & Boğaziçi SBUİ (784) \\
\hline 5 & ODTÜ Uİ (5980) & ODTÜ Uİ (3304) & ODTÜ Ul (73) & ODTÜ Ul (344) \\
\hline 6 & Yeditepe SBUI (5035) & Bilgi Uİ (2435) & İ. Medeniyet Uİ (68) & A. Sosyal B. Uİ (334) \\
\hline 7 & Bilgi Uİ (4462) & Yeditepe SBUİ (2331) & TOBB SBUI (52) & Işık Uİ (280) \\
\hline 8 & Kadir Has Uİ (3607) & Kadir Has Uİ (1898) & Kadir Has Uİ (48) & TR-Alman SBUİ (259) \\
\hline 9 & TOBB SBUİ (2540) & A. Sosyal B. UI (1574) & İzmir Eko SBUİ (43) & İ. Medeniyet Uİ (229) \\
\hline 10 & İÜ SBF SBUİ (2429) & İU SBF SBUİ (1533) & Başkent Uİ (35) & Başkent Ui (217) \\
\hline 11 & TR-Alman SBUİ (2399) & TOBB SBUİ (1500) & Boğaziçi SBUİ (33) & Bilgi Uİ (208) \\
\hline 12 & A. Sosyal B. Uİ (2213) & İ. Şehir SBUİ (1432) & Yaşar Uİ (31) & TOBB SBUİ (202) \\
\hline 13 & S. Zaim SBUİ (2200) & S. Zaim SBUİ (1428) & MEF SBUİ (28) & İzmir Eko SBUİ (202) \\
\hline 14 & İ.Şehir SBUİ (2192) & İ. Medeniyet Uİ (1380) & Ant. Bilim SBUİ (23) & Yaşar Uİ (172) \\
\hline 15 & Başkent Uİ (2118) & Başkent Uİ (1349) & Işık Uİ (22) & Ant. Bilim SBUİ (168) \\
\hline 16 & MEF SBUİ (1858) & TR-Alman SBUİ (1271) & Yeditepe SBUİ (21) & MEF SBUİ (150) \\
\hline 17 & İ. Medeniyet Uİ (1849) & Sakarya Uİ (1101) & İ. 29 Mayıs SBUİ (21) & İU İF SBUİ (131) \\
\hline 18 & Uludağ Uİ (1806) & H. Bayram Uİ (1087) & TR-Alman SBUİ (19) & Yeditepe SBUİ (130) \\
\hline 19 & Ankara Ü. Uİ (1748) & MEF SBUİ (1005) & Marmara UI (17) & Kadir Has Uİ (94) \\
\hline 20 & H. Bayram Uİ (1732) & Uludağ Uİ (992) & Hacettepe Uİ (16) & Altınbaş Uİ (92) \\
\hline 21 & Sakarya Uİ (1533) & Ankara Ü. Uİ (971) & Sakarya Uİ (16) & İ. Aydın SBUİ (80) \\
\hline 22 & Bahçeşeh. SBUİ (1503) & Işık Uİ (913) & S. Zaim SBUİ (16) & İ. 29 Mayıs SBUİ (75) \\
\hline 23 & Işık Uİ (1406) & Ant. Bilim SBUİ (792) & İb Haldun SBUİ (15) & Çankaya SBUİ (71) \\
\hline 24 & YTÜ SBUİ (1405) & YTÜ SBUI (766) & A. Sosyal Uİ (14) & S. Zaim SBUİ (60) \\
\hline 25 & İ. Aydın SBUİ (1337) & İ. Aydın SBUİ (759) & İÜ İF SBUİ (13) & İb Haldun SBUİ (57) \\
\hline
\end{tabular}

48 Sabancı Üniversitesi’nin "Uluslararası İlişkiler” adı altından lisans üstü programı varsa da, lisans program adı olarak "Uluslararası Çalışmalar” (UÇ) ismini kullanmaktadır. 
Tablo 6: Uİ ve SBUİ Bölümleri için Atıf/ Akademisyen Oranı üzerinden Google Scholar ve SSCI Sıralamaları

\begin{tabular}{|c|c|c|c|c|}
\hline & \multicolumn{2}{|c|}{ Google Scholar (GS) Atıfları } & \multicolumn{2}{|c|}{ SSCI Verileri } \\
\hline & GS Genel Atıf & GS 5-Yıl Atıf & Makale Sayısı & Toplam Atıf \\
\hline 1 & Koç Uİ (1192) & Koç Uİ (651) & Koç Uİ (142) & Koç Uİ (142) \\
\hline 2 & Sabancı UÇ (1197) & Sabancı UÇ (604) & Boğaziçi SBUİ (49) & Sabancı UÇ (85) \\
\hline 3 & Boğaziçi SBUİ (447) & Boğaziçi SBUİ (260) & A. Sosyal B. Uİ (27) & Bilkent Uİ (51) \\
\hline 4 & Kadir Has Uİ (360) & Bilkent Uİ (206) & Başkent Uİ (12) & Boğaziçi SBUİ (49) \\
\hline 5 & Yeditepe SBUİ (359) & Kadir Has Uİ (189) & Sabancı UÇ (11) & Işık Uİ (46) \\
\hline 6 & Bilkent Uİ (353) & TR-Alman Uİ (181) & İ. Aydın SBUİ (10) & TR-Alman Uİ (37) \\
\hline 7 & TR-Alman Uİ (342) & Yeditepe SBUİ (166) & Atılım Uİ (9) & A. Sosyal B. Uİ (27) \\
\hline 8 & Bilgi Uİ (262) & Işık Uİ (152) & Kadir Has Uİ (9) & Yaşar Uİ (25) \\
\hline 9 & ODTU Uİ (260) & ODTU Uİ (143) & Altınbaş Uİ (7) & İzmir Eko SBUİ (20) \\
\hline 10 & Işık Uİ (234) & Bilgi Uİ (143) & Bilkent Uİ (6) & MEF SBUİ (18) \\
\hline 11 & MEF SBUİ (232) & İb Haldun Uİ (139) & Yaşar Uİ (5) & Ant. Bilim SBUİ (18) \\
\hline 12 & İb Haldun Uİ (200) & A. Sosyal Uİ (131) & Marmara Uİ (4) & İ Medeniyet Uİ (15) \\
\hline 13 & A. Sosyal B. Uİ (184) & Medipol SBUİ (126) & İ. Medeniyet Uİ (4) & ODTU Uİ (14) \\
\hline 14 & Medipol SBUİ (181) & MEF SBUİ (125) & İzmir Eko SBUİ (4) & TOBB SBUİ (13) \\
\hline 15 & TOBB SBUİ (169) & İ. Şehir SBUİ (110) & Bilgi Uİ (4) & Başkent Uİ (12) \\
\hline 16 & İ. Şehir SBUİ (168) & TOBB SBUİ (100) & İb Haldun Uİ (3) & Bilgi Uİ (12) \\
\hline 17 & İ. Aydın SBUİ (166) & Yaşar Uİ (96) & ODTU Uİ (3) & İ. 29 Mayıs SBUİ (12) \\
\hline 18 & Yaşar Uİ (157) & İ. Aydın SBUİ (94) & TOBB SBUİ (3) & İb Haldun Uİ (11) \\
\hline 19 & Bahçeşehir SBUİ (150) & İ. Medeniyet Uİ (92) & Galatasaray Uİ (3) & İ. Aydın SBUİ (10) \\
\hline 20 & Uludağ Uİ (143) & Ant. Bilim SBUİ (88) & Işık Uİ (3) & Altınbaş Uİ (10) \\
\hline 21 & Ankara Uİ (134) & S. Zaim SBUİ (84) & S. Zaim SBUİ (3) & Atılım Uİ (9) \\
\hline 22 & Altınbaş Uİ (132) & Uludağ Uİ (79) & İ. 29 Mayıs SBUİ (3) & Kadir Has Uİ (9) \\
\hline 23 & Çankaya SBUİ (132) & Başkent Uİ (79) & MEF SBUİ (3) & Yeditepe SBUİ (9) \\
\hline 24 & Üsküdar SBUİ (131) & Sakarya Uİ (78) & Çukurova SBUİ (2) & Çankaya SBUİ (8) \\
\hline 25 & S. Zaim SBUİ (129) & Altınbaş Uİ (78) & A. Yıldırım B. Uİ (2) & İÜ İF SBUİ (6) \\
\hline
\end{tabular}

\section{Sonuç ve Değerlendirme}

Ortaya çıkan bu 5 farklı tabloyu yorumlamak gerekirse, sonuçlar Türkiye'deki Uİ akademisyenleri ve bölümlerine dair, üçü akademisyenlere dördü bölümlere ilişkin olmak üzere yedi önemli tespitte bulunma imkanı sağlamaktadır. Tablo 2'deki tüm akademisyenler cinsiyet temelinde tasnif edildiğinde, 4 kategoride de erkeklerin oranı yaklaşık yüzde 70 iken kadınların oranı yüzde 30'dur. Tablo 3'te ise kadınların oranı \%30'un üzerinde iken, SSCI atıf kategorisinde bu oran \%35'e kadar çıkmaktadır. ABD’deki Siyaset Bilimi bölümlerinde bulunan ve atıf sayısı en yüksek ilk 20 kişinin cinsiyet oranı (yaklaşık yüzde 90 erkek) ${ }^{49}$ ile karşılaştırıldığında Türkiye'de Uluslararası ilişkiler

49 Peress, "Measuring the Research Productivity", s. 316. 
disiplini içinde yüksek atıf sayısına sahip kadın akademisyen oranının göreli olarak fazla olduğu söylenebilir (bkz. Tablo 7). İkinci olarak, Tablo 3'teki Google Scholar 5-Yıl atıf sıralaması ile SSCI Atıf sıralaması karşılaştırıldığında isimlerin yaklaşık yüzde 70’inin aynı olduğu ortaya çıkmıştır. Buradan hareketle akademisyenlere ilişkin GS verilerinin önemli ölçüde bir nitelik göstergesi olduğu sonucuna varılabilir.

Tablo 7: Uİ Çalışan Akademisyenlerin Cinsiyete Göre Google Scholar ve SSCI Sıralaması

\begin{tabular}{|c|c|c|c|c|}
\hline \multicolumn{5}{|c|}{ Kadın Akademisyenler } \\
\hline & \multicolumn{2}{|c|}{ Google Scholar (GS) Atıfları } & \multicolumn{2}{|c|}{ SSCI Verileri } \\
\hline & GS Genel Atıf & GS 5-Yil Atıf & Makale Sayısı & Toplam Atıf \\
\hline 1 & Ptnar Bilgin (2574) & Ptnar Bilgin (1506) & Meltem Müftüler-Baç (25) & Ptnar Bilgin (376) \\
\hline 2 & Meltem Müftüler-Baç (2197) & Meltem Müftüler-Baç (1087) & Pinar Bilgin (19) & Bahar Rumelili (327) \\
\hline 3 & Bahar Rumelili (1453) & Bahar Rumelili (860) & Bahar Rumelili (18) & Meltem Müftüler-Baç (240) \\
\hline 4 & M. Altunışık (1278) & M. Altunışık (746) & Ç. Kentmen (14) & R. Karakaya Polat (212) \\
\hline 5 & Senem Düzgit (1134) & Senem Düzgit (676) & Şuhnaz Yilmaz (13) & Şuhnaz Yilmaz (142) \\
\hline 6 & R. Karakaya Polat (934) & R. Karakaya Polat (548) & M. Altunışık (11) & Aylin Güney (128) \\
\hline 7 & H. D. Yükseker (879) & H.D. Yükseker (526) & Emel P.Dal (11) & M. Altunışık (94) \\
\hline 8 & Aylin Güney (607) & Şuhnaz Yilmaz (342) & Senem Düzgit (10) & Senem Düzgit (88) \\
\hline 9 & Şuhnaz Yilmaz (561) & Özlem Tür (337) & Aylin Güney (10) & H. D. Yükseker (80) \\
\hline 10 & Özlem Tür (537) & Aylin Güney (297) & R. Karakaya Polat (9) & Ç. Kentmen (73) \\
\hline 11 & Beril Dedeoğlu (450) & Deniz Sert (278) & Özlem Altan (9) & Özlem Tür (49) \\
\hline 12 & Gülnur Aybet (383) & Banu Eligür (242) & Özlem Tür (8) & Özlem Altan (43) \\
\hline 13 & Melek Firat (345) & Beril Dedeoğlu (221) & Asli Ilgit (7) & B. Saatçioğlu (43) \\
\hline 14 & Deniz Sert (340) & Nurcan Ö. B.Oğlu (209) & Pinar İpek (6) & Gözde Yılmaz (43) \\
\hline 15 & Sinem Açıkmeşe (319) & Emel P. Dal (205) & Ebru Boyar (6) & Gülnur Aybet (31) \\
\hline \multicolumn{5}{|c|}{ Erkek Akademisyenler } \\
\hline 1 & Ziya Öniş (8083) & Ziya Öniş (3654) & Ziya Öniş (40) & Ziya Öniş (925) \\
\hline 2 & Fuat Keyman (4234) & Fuat Keyman (2157) & Bülent Aras (36) & Resul Yalçın (292) \\
\hline 3 & Bülent Aras (2613) & Bülent Aras (1371) & Ayhan Kaya (23) & Fuat Keyman (274) \\
\hline 4 & Ayhan Kaya (1922) & Ayhan Kaya (1199) & Fuat Keyman (21) & Murat Somer (224) \\
\hline 5 & Mustafa Aydın (1592) & Mustafa Aydın (747) & Ersel Aydınlı (19) & Bülent Aras (187) \\
\hline 6 & İlter Turan (1216) & Resul Yalçın (555) & Cengiz Erişen (16) & Ersel Aydınlı (160) \\
\hline 7 & İhsan Dağı (1059) & Tarık Oğuzlu (551) & Murat Somer (15) & Caner Bakur (152) \\
\hline 8 & Tayyar Arl (1025) & Tayyar Arı (543) & Tarık Oğuzlu (14) & Tarık Oğuzlu (128) \\
\hline 9 & Tarık Oğuzlu (864) & G. Çetinsaya (537) & M. Kibaroğlu (14) & Fougner Tore (122) \\
\hline 10 & Ersel Aydınlı (833) & İhsan Dağ $(505)$ & Mustafa Aydin (13) & Ayhan Kaya (109) \\
\hline 11 & Murat Somer (803) & Murat Somer (495) & Caner Bakır (13) & N. Ali Özcan (92) \\
\hline 12 & G. Çetinsaya (789) & Ali Balcı (460) & M. Biresselioğlu (11) & Cengiz Erişen (89) \\
\hline 13 & M. Kibaroğlu (727) & İlter Turan (459) & Şener Aktürk (10) & Alper Kaliber (78) \\
\hline 14 & Resul Yalçın (717) & Ersel Aydınlı (451) & D. Tsarouhas (10) & Reşat Bayer (73) \\
\hline 15 & Çağrı Erhan (588) & Şener Aktürk (420) & N. Ali Özcan (9) & Şener Aktürk (72) \\
\hline
\end{tabular}

Doktora dönemlerine göre yapılan sıralama tablosuna (Tablo 4) bakıldığında iki konuda çıkarım yapma imkanı bulunmaktadır. Birincisi ve beklenildiği üzere kıdemli olanlar Tablo 3'te daha fazla temsil edilmektedir. Öte yandan, SSCI verileri göz önüne alındığında, 2008-2012 
yıllarında doktorasını alan akademisyenlerin tamamı Tablo 3'teki sıralamada kendilerine yer bulmuştur. GS verileri özelinde ise söz konusu akademisyenlerin yaklaşık yarısının Tablo 3'te olduğu görülmektedir. Buradan hareketle, görece genç akademisyenlerin akademik etki noktasında başarılı oldukları söylenebilir. Bir diğer çıkarım ise doktora alınan ülkeler ile ilgilidir. 2003 öncesi kıdemli akademisyenlerden Türkiye doktoralı sadece bir kişi (Bülent Aras) SSCI atıfları ve GS son 5 yıl atıfları listesine girebilmiştir. Benzer veriler bağlamında 2008-2012 döneminde doktorasını almış olan akademisyenlere bakıldığında GS son 5 yıl atıfları listesine 4 Türkiye doktoralı ismin, SSCI atıflar listesine de 2 Türkiye doktoralı ismin girdiği görülmektedir. Bu iki karşılaştırmadan hareketle Türkiye'de Uİ doktora programlarının bir gelişme gösterdiği sonucuna varılabilir (Bkz. Şekil 1).

Şekil 1: Doktora Alma Dönemlerine Göre Atıf/Yayın Sayllarında İlk 10’a Giren Türkiye Doktoralı Akademisyenlerin Sayısı

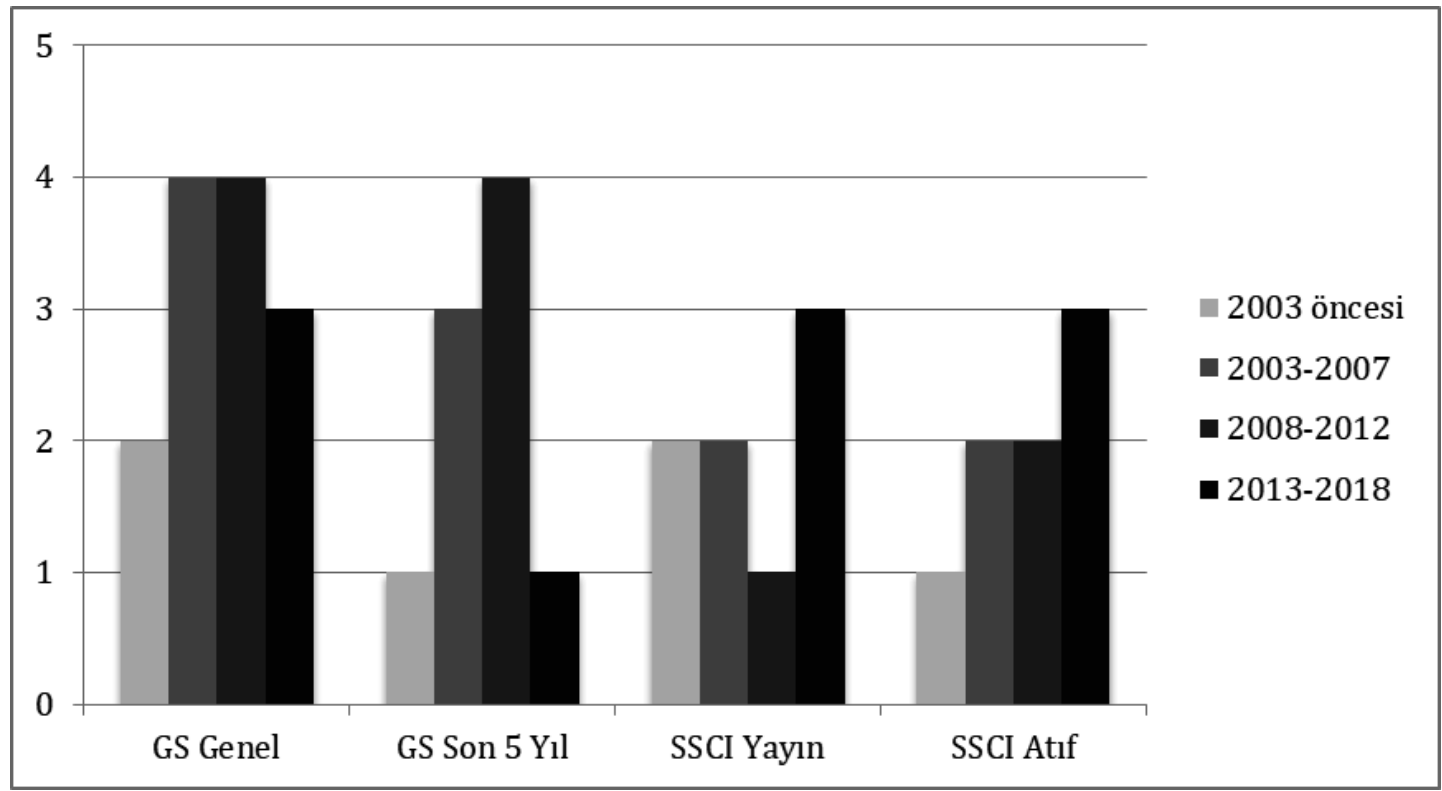

Bölümler ile ilgili tespitlere bakılacak olursa, vakıf üniversitelerinin devlet üniversitelerine oranla Uİ bölümleri bazında daha başarılı bir performans ortaya koydukları söylenebilir. SSCI verilerine bakıldığında vakıf üniversitelerindeki bölümlerin başarı oranı daha da artmaktadır. Tablo 5'teki GS verilerinin her ikisinde de 10 devlet üniversitesi yer alırken, SSCI toplam atıf istatistiklerinde sadece 6 devlet üniversitesi kendilerine yer bulabilmiştir. Atıf sayıları bölümlerde istihdam edilen akademisyen sayısına bölündüğünde ortaya çıkan rakamlar üzerinden bir karşılaştırma yapılırsa, vakıf üniversiteleri GS verilerinde de devlet üniversiteleri ile arayı açmıştır. Örneğin, Genel GS Atıfları istatistiğinde sadece 6 devlet üniversitesinin tabloya girebildiği görülmüştür. Bölümler bazında GS ve SSCI verileri üzerinden yapılacak bir karşılaştırma farklı bir tespit olarak değerlendirilebilir. Buna göre her iki kategorideki üniversitelerin sıralamaları önemli ölçüde örtüşmüş ve buradan hareketle akademisyen karşılaştırmasında olduğu gibi GS verilerinin bir nitelik göstergesi olduğu görülmüştür. 
Yine bölümlerle ilgili olan bir başka tespit de, Ankara ve İstanbul'daki bölümlerin ilk 25'e hakim olduklarıdır. Tablo 5 ve 6'daki (diğer üniversitelerin en başarılı kategorisi olan) son beş yıllık GS atıf verilerine baktığımızda her ikisinde de sadece 4 üniversitenin Türkiye’nin başka şehirlerinden olduğu görülmektedir. Dolayısıyla her iki tabloda da ilk 25'e giren bölümlerin yüzde 85 'den fazlası Ankara ve İstanbul'da konumlanmış durumdadır. Yine bölümler bazında yapılabilecek bir başka tespit de, GS genel atıf verileri ile GS son 5 yıl atıf verilerinin karşılaştırması hakkındadır. Buna göre, 3 devlet üniversitesi son beş yıllık verilerde 2 ve daha fazla sıra üste çıkarak performansını artırırken, vakıf üniversitelerinde 2 bölüm benzer performans artışı gerçekleştirmiştir. Bu noktada verilerin çok güçlü desteklemediği bir yorum olsa da, devlet üniversitelerinin atıf performansında bir ilerleme olduğu söylenebilir.

Son olarak, bu çalışmanın Türkiye'deki sıralama (ranking) literatürüne üç önemli katkı yaptığından bahsedilebilir. İlki, Aydın ve arkadaşlarının Uİ mensubu akademisyenler arasında yaptıkları en son yayımlanan (2014 tarihli) anket sonuçları ile karşılaştırıldığında varılabilecek sonuçlara ilişkindir. Uİ alanında en etkili yayınları yaptığı düşünülen 4 isim (Pınar Bilgin, Mustafa Aydın, Ziya Öniş ve Fuat Keyman) Tablo 3'teki GS Genel Atıflar sıralamasında ilk 10'da yer almıştır. ${ }^{50}$ Buradan hareketle akademisyenler arasındaki algı ile somut ölçülebilir verilerin ortaya çıkardığı tablonun önemli ölçüde örtüştüğü sonucuna varılabilir. Yine Aydın ve arkadaşlarının anketinde Uİ lisansı okumak isteyen öğrenciler için en iyi üniversiteler hangileridir sorusuna verilen cevaplar ile ortaya çıkan 10 bölümden 8 tanesi, bu çalışmada yer alan Tablo 5'teki Google Scholar Genel atıflar listesinin ilk 11'i arasına girebilmiştir. ${ }^{51}$ Sadece Marmara Üniversitesi (listede yok) ve Ankara Üniversitesi (19. sırada) anketten çıkan sonuçlar ile örtüşmemektedir. Bu konuda da akademisyenlerin algısı ile ölçülebilir verilerden çıkan sonuçların önemli ölçüde benzerlik gösterdiği söylenebilir.

Çalışmanın sıralama literatürü açısından ikinci önemi ise GS'ın SSCI ile önemli oranda örtüşen bir nitelik ölçme kriteri olduğu noktasındaki tespittir. Bu da Aydın ve arkadaşlarının anketinde "bir akademisyenin alandaki etkisini değerlendirirken hangi kritere bakarsınız" temalı sorusuna verilen cevaplar ile kısmen örtüşmektedir. İlgili ankette ilk iki sırada bulunan SSCI ve GS için 'Önemli' ve 'Çok Önemli’ cevabını işaretleyenlerin oranı sırasıyla yüzde 69 (her 100 kişiden 69'u önemli buluyor) ve yüzde 42 (her 100 kişiden 42 si önemli buluyor) şeklindedir. ${ }^{52}$ Yukarıda akademisyenler ve bölümler kategorilerinde SSCI verileri ile GS verilerinin önemli ölçüde benzeştiği tespiti yapılmıştı. Buna ek olarak, yine bu çalışmada Tablo 3'te yer alan SSCI toplam atıflar listesi ile GS son 5 yıl atıfları listesi karşılaştırıldığında SSCI toplam atıflar listesindeki ilk 25 isimden sadece 2'sinin GS son 5 yıl atıfları listesinde olmadığı görülmektedir. Bu karşılaştırma da veri sonuçlarındaki benzerliğin yüksekliği hakkında bir fikir vermektedir.

Son olarak, GS verileri üzerinden Türkiye’ye özgü bir sıralama yapan ilk araştırma olması çalışmayı benzerlerinden ayırsa da, tam da bu özelliği sebebiyle bu çalışmanın önemli eksikleri bulunmaktadır. Örneğin ortaya çıkan GS sonuçlarından hareketle zamansal bir karşılaştırma yapma imkanı yoktur. Bu bağlamda çalışma, 'hangi üniversiteler GS son beş yıl atıfları bazında yükselme eğilimi içindedir?’ sorusunu cevaplayamaz. Fakat daha sonra yapılacak benzer içerikli çalışmalar

50 Aydın et al., “Türkiye’de Uluslararası İlişkiler Akademisyenleri”, s. 24.

51 Ibid., s. 25; Benzer şekilde, öğrenci alımında taban puanı en yüksek 4 üniversite ile Tablo 4’teki tüm kategorilerde ilk 4'e giren üniversiteler aynıdır.

52 Ibid., s. 21. 
böyle bir karşılaştırma imkanı sunabilir. Yine bu çalışma ortaya çıkan verilerden hareketle bölüm karşılaştırması yapabilse de, üniversiteler arasında genel bir karşılaştırma yapma imkanına sahip değildir. Ancak ilerleyen yıllarda farklı bölümlere yönelik yapılacak benzer içerikli çalışmalar sayesinde hangi üniversitenin hangi alanlarda daha fazla öne çıktığına yönelik çıkarımların yapılması mümkün olabilecektir. Son olarak ise, GS verileri akademik etkinin ölçülmesi noktasında ham veri sunmaktadır ve bu verilerin akademik etki ile ilgili bir çok dinamik ile kontrol edilmesi gerekmektedir. Örneğin, belirli bir temada yazmış olmaktan ya da bir teorik çizgiye ait olmaktan kaynaklanan yüksek atıf sayısının ortaya çıkardığı avantajlı durumun akademik etki karşılaştırmalarında nasıl ortadan kaldırılacağı konusu yeni detaylı çalışmaları beklemektedir. 